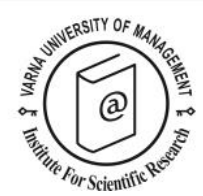

\title{
Investigation of the Motivations and Experiences of Tourists Visiting the Gallipoli Peninsula as a Dark Tourism Destination
}

\author{
Kadir Çakar ${ }^{1 *}$
}

\begin{abstract}
${ }^{1}$ Mardin Artuklu University, Faculty of Tourism, Kabala Mahallesi, Kabala Merkez, 4708o Artuklu, Mardin, Turkey. Email: kadircakar@artuklu.edu.tr

* Corresponding author
\end{abstract}

\begin{abstract}
The present study strives to understand the travel motivations and experiences of both domestic and international travellers visiting the Gallipoli Peninsula. Qualitative research methodology was utilized for this study, with a case study approach employed for the qualitative research design. Data were gathered using face-to-face interviews $(n=44)$, participant observation and document analysis, and an inductive content analysis was then used to analyse the data. The research findings revealed that travellers visiting the site have different motivations and experiences, as well as some commonalities. The findings also indicate that those visiting the site have different travel motivations and experiences, as well as commonalities. Their travel motivations form a heterogeneous pattern, including push and pull motivational factors, while experiences can be grouped into psychological and sociocultural categories; these are useful contributions to the existing literature in the field. As a consequence, the results of this study are unique as they show that battlefield sites within the scope of the dark tourism phenomenon may offer visitors memorable tourism experiences and socio-cultural experiences.
\end{abstract}

Keywords: Dark Tourism, Motivation, Experience, The Case of Gallipoli

Citation: Çakar, G. (2020). Investigation of the Motivations and Experiences of Tourists Visiting the Gallipoli Peninsula as a Dark Tourism Destination. European Journal of Tourism Research 24, 2405 


\section{Introduction}

Travellers' visits to locations or landscapes related to death, disasters or atrocities, once described as dark tourism by Foley and Lennon (1996a; 1996b; Stone and Sharpley, 2008), continue to receive a great deal of attention from scholars. While this type of tourism is intertwined with heritage places, the use of the concept is associated with wide-ranging and varied terms, namely thanatourism, death tourism and dark heritage (Ivanova and Light, 2017). Many different sub-forms manifest from within the concept of dark tourism (Váquez, 2018), such as battlefield tourism (Chen and Tsai, 2019; Pennell, 2018), prison tourism (Strange and Kempa, 2003; Wilson et al., 2017), post-disaster tourism (Lin et al., 2018) and Dracula tourism (Banyai, 2010; Light, 2007), while also encompassing areas or venues where celebrities have died (Stone, 2005), concentration camps (Isaac et al., 2019; Nawijn and Fricke, 2015; Podoshen, 2017) and so-called slave castles (Boateng et al., 2018). Although a number of studies have been carried out so far, there is still something of a gap in the extant literature dealing with the dimensions of both consumer motivation and experience, which the present paper aims to fill.

In this study, the motivations and experiences of local and foreign tourists (including from Australia, New Zealand, Turkey, and other countries) who have visited Dardanelles in the context of dark tourism were studied in depth using a qualitative, comparative approach. This study is expected to make two basic contributions to the literature. Its first contribution will be as an extensive and in-depth study, using a qualitative method to discover the similarities and differences between tourists of different nationalities and cultures with regard to their motivation to visit a destination and their experiences of that destination in the context of dark tourism. Second, and indeed the most important contribution, will be as a comparative study of the motivations and tourism experiences of tourists from countries that participated in the Dardanelles Campaign.

\section{Literature Review}

\section{The Concept of Dark Tourism}

Dark tourism is defined as visiting places that are offered as marketable tourism products where important incidents took place in the past, such as natural disasters and wars, which resulted in deaths and tragedy (Foley and Lennon, 1996a, 2000; 2005; Sharpley, 2009; Wright and Sharpley, 2018). The media and its impact are shown as factors that have contributed to the emergence and development of the dark tourism phenomenon (Foley and Lennon, 1996a; 1996b; Korstanje, 2011). It has also been claimed, in related fields in the literature, that postmodernism has played a significant role in this type of tourism gaining such popularity (Muzaini, et al., 2007). The concept of dark tourism has gained greater significance as an area of research in the $21^{\text {st }}$ century, in particular due to the increasing interest in death and disaster in postmodern societies (Powell and Iankova, 2016, Powell and Kennel, 2016). The type of tourism in question also comes to the fore as a sub-branch of special interest tourism, which has developed mostly on a cultural basis (Kozak and Bahçe, 2012; Minic, 2012). Consequently, places offered for the consumption of tourists within the scope of dark tourism are referred to as cultural heritage sites (Hartmann, 2014).

It was Rojek (1993) who first referred to places that attract tourists following the sudden deaths of celebrities or a large number of people, and are consequently commercialised, as "black-spots". Taking a similar approach, Foley and Lennon (1996a) used the term "dark tourism" to describe this phenomenon and Seaton (1996) contributed to a related field in the literature with the concept of "thanatourism". Later, Lippard (1999) brought a different insight to the dark tourism phenomenon with the term "tragic tourism", while Blom (2000) used the term "morbid tourism" to illustrate this concept. Since then, Sharpley (2005) has described the dark tourism phenomenon as "grief tourism" whereas 
Clark (2010) has defined this phenomenon as "trauma tourism”. Lastly, Miller and Gonzales (2013) have further developed the concept by delineating it as "death-tourism" within the context of dark tourism. According to Lennon (2005), dark tourism is not a new phenomenon but began in the Middle Ages with visits to places associated with the past, such as cemeteries, including martyrs' cemeteries, which had particular importance for people's beliefs. In this context, the locations of the Battle of Waterloo in 1815 , the American Civil War, and Ground Zero in New York, where 9/11 took place, have all became popular places for dark tourism (Coldwell, 2013).

Another important place that can be evaluated within the scope of dark tourism is the Auschwitz concentration camp in Birkenau, Poland (Miles, 2002; Podoshen and Hunt, 2011). Initially, this place had only symbolic value following World War II but it has since been turned into a museum and has become a popular tourism destination with visitors from all over the world. A report in 2014 showed that the museum has been visited by more than 1.5 million people (Auschwitz Report, 2014).

Other major locations that have dark tourism potential with international popularity are the Tuol Sleng Genocide Museum in Cambodia (Coldwell, 2013; Sion, 2014), Robben Island Jail in South Africa, Alcatraz Prison in California, USA (Strange and Kempa, 2003), the Holocaust Memorial Museum in Washington D.C., USA (Lennon and Foley, 1999; Miles, 2002), Gallipoli in Çanakkale, which is considered one of the most important locations of World War I (WWI, 1914-1918) (Hall et al., 2010; Hyde and Harman, 2011; Slade, 2003; Ozer, Ersoy and Tuzukan, 2012; Cheal and Griffin, 2013), the Pacific war field of World War II (WWII, 1941-1945) (Cooper, 2006), the place where President Kennedy was assassinated in Dallas, Texas, USA (Foley and Lennon, 1996b) and the Chernobyl nuclear disaster area in Ukraine (Goatcher and Brunsden, 2011; Schafer, 2016; Stone, 2013a; Yankovska and Hannam, 2014). In a similar way, places where natural catastrophes such as earthquakes and tsunamis have occurred are also evaluated within the category indicated above, as places offering tourist experiences in the context of dark tourism (Amujo and Otubanjo, 2012; Biran, Liu, Li and Eichborn, 2014; Lin et al., 2018).

As dark tourism mostly offers educational and emotional experiences (Biran et al., 2011; Henderson, 2000; Kang et al., 2012), it has been observed that the motivations of tourists visiting such destinations depend on several factors (Light, 2017; Liyanage et al., 2015). Generally speaking, education, remembrance, the enhancement of national identity, and interest and curiosity about history are the primary motivations for dark tourism (Bigley et al., 2010; Cheal and Griffin, 2013; Farmaki, 2013; Isaac and Çakmak, 2013; Ivanova and Light, 2018; Kang et al., 2018; Raine, 2013; Yuill, 2003; Winter, 2011b; Zheng et al., 2018).

The most common underlying motivation among tourists seeking dark tourism experiences is collective memory and the need for empathy that arises from this (Miles, 2002). In this context, another component of the dark tourism phenomenon are the memories of past tragic incidents that have often resulted in deaths, that have a place in a society's collective memory (Conway, 2010). Another aspect of the emergence and growth of dark tourism that must be emphasized is that it is formed by both supply and demand (Raine, 2013; Smith and Croy, 2005; Stone, 2006).

\section{Battlefield Tourism in the Context of Dark Tourism}

Battlefields and military cemeteries began to be regarded as sacred places in the $19^{\text {th }}$ century (Gatewood and Cameron, 2004). Battlefield tourism is a type of dark tourism in which museums are founded for tourists in places where battles took place (Dunkley et al., 2011). Visitors to such places regard them as heritage sites and attribute new meanings that they have acquired as a result of the historical events that took place there. Evaluated in this context, celebration activities organized in the name of the 
protection of such places and their presentation become very important (Winter, 2008). The phenomenon of battlefield tourism, which focuses on places associated with conflicts such as the Napoleonic Wars, the American Civil War and World Wars I and II, can be evaluated with reference to different locations and tourist attractions and regarded as important (Henderson, 2000). In a similar way, after the Spanish Civil War, places where traces of the war could be found, such as battlefields, prisons and cemeteries, were protected, restored and transformed into tourism products that were then opened up to tourists (Smith, 2007).

One of the best examples of battlefield tourism is the location of the Battle of Waterloo that took place in 1815. The field where the battle took place is regarded as the most important example of battlefield tourism; it continued to be a popular destination until the outbreak of WWI in 1914 and even today is considered the second most important place in terms of its tourism potential (Seaton, 1999). Battlefield tourism has grown in popularity, especially since WWI, with increased visits following the establishment of monuments and museums in places where battles took place (Baldwin and Sharpley, 2009).

The phenomenon of battlefield tourism expresses an evaluation and presentation of battlefields in the context of collective memory, memory that is then institutionalized through memorial ceremonies and museums, which become tourism products for consumption purposes (Misztal, 2003). The generations that followed WWI played a vital role in the commemoration of those who lost their lives as a result of the war through the creation of a collective memory of the events of the past (Winter, 2009). Accordingly, battlefields presented as cultural heritage sites for tourism purposes are also defined as places that are visited in order to show respect to those who suffered and died during those conflicts (Leopold, 2007).

Battlefield tourism is also considered a phenomenon that can create nationalistic feelings among visitors from the nations that took part in the conflict (Prideaux, 2007). The tragic events of the past have not only changed levels of understanding, acceptance and comprehension of the world, but also the roles of individuals in their own lives, whilst at the same time reshaping the heritage of the cultures and countries to which they belong (Leopold, 2007). In this context, as well as being attractive in a national sense and at a cultural level, war memorials and museums can also become important at the international level (Seaton, 1996).

An examination of the literature reveals a debate over whether visits to battlefields, evaluated in the context of dark tourism, are made for religious or secular reasons (Stephens, 2014). In this context, the development and growth of battlefield tourism suggests that such locations are considered sacred due to their historical importance; consequently, they are invested with spirituality and can be regarded as examples of cultural pilgrimage in a modern sense (Collins-Kreiner, 2010a; 2010b; 2016; Stone, 2005). Thus, visits made by Australians and New Zealanders to the Gallipoli Peninsula every year are regarded as part of the process of nation-state building and are invested with a symbolic spiritual value; this in turn means it can be evaluated as a secular pilgrimage in a cultural sense (Hall, 2002; Kokkranikal et al., 2015; Ryan, 2007a; Seaton, 2002).

Other destinations that are visited by tourists for the purpose of gaining experiences are the Pacific War area (Cooper, 2006, Cooper, 2007), places where the Vietnam War took place (Henderson, 200o; Willis, 2014), locations that featured during WWI such as the Trentino region of Italy (Irimias, 2014), the Somme and Ypres regions in France and Belgium, respectively (http://www.battlefields-tours.com/, 2015) and the Gallipoli Peninsula where the Dardanelles Campaign took place (Scates, 2002; Slade, 2003; 
Aliağaoğlu, 2008; Hyde and Harman, 2011; Hall et al., 2010; Ozer et al., 2012). These constitute examples of battlefield tourism that are significant at the international level. Battlefield tourism that has become popular in the context of dark tourism has been examined by several authors from different perspectives. While some of these studies put their focus on the supply-side (see Irimiás, 2014; Virgili et al., 2018; Winter, 2011a), many of them strived to investigate the demand-side of different battlefield landscapes (i.e. Bigley et al., 2010; Chen and Tsai, 2019; Miles, 2014). On the other hand, the vast majority of studies have concentrated on the relationships between individuals and war-related areas, further investigating the reasons people engage with such places (Iles, 2008), along with the impacts of communities' interpretations of such locations (Hurt, 2010; Knox, 2006). More importantly, it has been found that there is a strong relationship between war-related sites and dark tourism (Gordon, 1998; Johnston, 2011; Pieris, 2014; Smith, 1998); likewise, battlefield tourism creates positive economic impacts for the host communities that organize commemorative events (Hall and Basarin, 2009).

\section{Study Area}

For the purpose of this study, the Gallipoli Peninsula Historical National Park was selected as the research area. The Dardanelles-Gallipoli district, located in the Marmara region of Turkey, has significant potential for battlefield tourism within the scope of the dark tourism phenomenon as it was the location of several important WWI battles. Thanks to its historical and cultural aspects and tourism potential, the region hosts tourists from all over the world every year. The Dardanelles Province and Gallipoli Peninsula are primarily known as the place where an important WWI battle took place. Soldiers from Australia and New Zealand also participated in this battle, fighting with the English and French forces, and were known as "Anzacs” (Sackett, 1985; Scates, 2006).

During the war, of the 50,00o Australian soldiers who participated in the battle, 8,709 were killed and 18,235 wounded. The number of New Zealander soldiers killed totalled 2,701 with 4,88o wounded (Hall, 2002). The Ottoman army's losses were reported as 57,00o (Yeneroğlu-Kutbay and Aykaç, 2016). The British Empire's purpose was to conquer Istanbul by spreading around the Dardanelles region with the help of the Anzac soldiers, in order to strengthen the connection between France and England. A battle took place on the Gallipoli Peninsula, which the Turkish army won (Aliağaoğlu, 20o8; Cheal and Griffin, 2013; Hall, 2002; Piersig, 1994). This district is known for its many historical, cultural and tourism assets, including several archaeological and historical sites, examples of civil architecture, and military, administrative and industrial buildings (www.canakkalekulturturizm.gov.tr, 2016).

While the Dardanelles region is important for Turks, it also has a special importance for citizens of Australia and New Zealand (Prideaux, 2007). Therefore, tourists from Australia and New Zealand come to commemorate their relatives who lost their lives during the battle that took place there (Hyde and Harman, 2011). Every year, hundreds of thousands of tourists visit the region, and commemoration ceremonies are held for Anzac and Turkish people on different days (Stephens, 2014).

Since the battle, the $25^{\text {th }}$ of April has been commemorated as Anzac Day, as it was the day when Anzac troops arrived in the Gallipoli Peninsula; commemoration ceremonies are held for citizens of Australia and New Zealand on that day (Graham, 2008; Hede and Hall, 20o6; Wheatley and James, 2014). This date and this place are psychologically important for Australians and New Zealanders as it is considered to be the time and place when their respective nations were born (Donoghue and Tranter, 2015; Ozer, Ersoy and Tuzunkan, 2012; Slade, 2003). Similarly, the victory won in this war is accepted as the starting point of the Republic of Turkey's process of becoming a nation state in the modern sense; consequently, great importance is attributed to this battle (McKenna and Ward, 2007), visits are made by local tourists, and commemoration ceremonies are held every year on the $18^{\text {th }}$ of March. 
The Gallipoli Peninsula has been turned into a national park, and after the signing of the Lausanne Peace Treaty in particular, cemeteries, monuments, mausoleums and statues began to be built for those who lost their lives (Dore, 2006). In addition, through a joint project developed by the governments of Australia, New Zealand and Turkey, the site was renamed the "Gallipoli Peninsula Peace Park" (Catalca and Yurtseven, 2003). The Gallipoli Peninsula is known as a popular destination attracting both domestic and international tourists from all over the world, all year round. Dark tourism is especially important in this context as such activities are conducted throughout the year (Kurnaz et al., 2013).

\section{Methodology}

In this study, qualitative research methodology was thought to be beneficial. A case study approach was used as the qualitative research design. The data were collected through face-to-face interviews, participant observation and written and visual documents related to the region, which were then analysed through an inductive analysis.

Qualitative research methodology refers to an approach that allows people to examine their experiences in depth by using specific research methods such as in depth-interviews, focus group discussions, observation, content analysis, visual methods and life stories or biographies (Hennink et al., 2011). Qualitative research methods, unlike quantitative methods, benefit different research strategies that use various data collection techniques, analysis and interpretation based on distinct philosophical assumptions (Creswell, 2009).

Semi-structured interviews were conducted with questions focusing on two important issues, in accordance with the stated purpose of the research. These two issues centred around understanding the participants' motivations for visiting the region and the experiences they obtained from their visits.

1. What were (your) main motivations for visiting this site/region?

2. What were you most affected by during your visit? What were the most powerful elements that made your visit memorable as a tourism experience?

Interviews were conducted with tourists that had participated in commemoration ceremonies held at Dardanelles-Gallipoli between 24-26 April 2016 and between 7-10 August 2016.

\section{Research Design, Data Collection and Data Analysis}

In accordance with the purpose of the research, a qualitative research method was used. To begin, it is appropriate to explain the reasons for this choice of method, as well as its type and characteristics.

In this study, face-to-face interviews, document analysis and participant observations were the data sources used. The study utilized the snowball sampling technique as a purposeful sampling method in order to obtain in-depth information regarding the phenomenon under investigation. During the research phase, interviews were conducted with a total of 44 domestic and foreign tourists; three of these interviews were conducted over the telephone while one participant preferred to take part by answering the questions via e-mail. The rest were conducted face-to-face. Another participant did not consent to the use of voice recording devices, and so their answers were recorded in writing only.

Data obtained from this study were analysed through an inductive content analysis. The concepts that emerged were sorted into themes, which were then divided into meaningful categories. The data was then transcribed from audio recordings into written text and a coding process was implemented. For better understanding and interpretation, this was supported with direct quotations. 
Information regarding the Study Group

The participants consisted of 25 men and 19 women, while 28 of them were international tourists and 16 were domestic tourists. 35 of the participants were visiting the site for the first time, six were making a second visit, two were visiting for the fifth time while the remaining participants stated simply that they had visited the site more than once. The countries of origin of the tourists in the study were Australia (21), the Republic of Turkey (13), New Zealand (2), England, UK (2), Germany (2), Belgium (1), Canada (1), Portugal (1) and Scotland, UK (1) (see Table 1).

Table 1. Demographic data for participants

\begin{tabular}{|c|c|c|c|c|c|c|}
\hline Participant & Age & Gender & Occupation & Nationality & $\begin{array}{l}\text { Country of } \\
\text { Residence }\end{array}$ & $\begin{array}{l}\text { Frequency of } \\
\text { Visit }\end{array}$ \\
\hline $\mathrm{P}_{1}$ & $60-65$ & $\mathrm{M}$ & Chef & $\mathrm{AU}$ & $\mathrm{AU}$ & 1 \\
\hline $\mathrm{P}_{2}$ & 30 & $\mathrm{~F}$ & Radiographer & $\mathrm{AU}$ & UK & 1 \\
\hline $\mathrm{P}_{3}$ & 26 & $\mathrm{~F}$ & Retail & $\mathrm{AU}$ & UK & 1 \\
\hline $\mathrm{P}_{4}$ & 27 & $\mathrm{M}$ & Engineer & $\mathrm{AU}$ & UK & 1 \\
\hline $\mathrm{P}_{5}$ & 28 & $\mathrm{M}$ & Pharmacist & $\mathrm{AU}$ & $\mathrm{AU}$ & 1 \\
\hline P6 & $40-45$ & $\mathrm{~F}$ & $\begin{array}{l}\text { Volunteer } \\
\text { Educator }\end{array}$ & $\mathrm{AU}$ & $\mathrm{AU}$ & 1 \\
\hline $\mathrm{P}_{7}$ & 87 & $\mathrm{M}$ & Retired & UK & UK & 2 \\
\hline P8 & 23 & $\mathrm{M}$ & Life Saver & $\mathrm{AU}$ & $\mathrm{AU}$ & 1 \\
\hline $\mathrm{P9}$ & 24 & $\mathrm{~F}$ & Logistics & $\mathrm{AU}$ & $\mathrm{AU}$ & 1 \\
\hline P10 & 29 & $\mathrm{~F}$ & Teacher & $\mathrm{AU}$ & $\mathrm{AU}$ & 1 \\
\hline P11 & 35 & $\mathrm{M}$ & Film Producer & $\mathrm{AU}$ & UK & 1 \\
\hline $\mathrm{P}_{12}$ & 26 & $\mathrm{~F}$ & $\begin{array}{l}\text { Environmental } \\
\text { Advisor }\end{array}$ & AU & $\mathrm{AU}$ & 1 \\
\hline $\mathrm{P}_{13}$ & 28 & $\mathrm{M}$ & $\begin{array}{l}\text { Marine } \\
\text { Engineer }\end{array}$ & $\mathrm{AU}$ & AU & 1 \\
\hline $\mathrm{P}_{14}$ & 72 & $\mathrm{M}$ & Retired & $\mathrm{AU}$ & AU & 1 \\
\hline $\mathrm{P}_{15}$ & 67 & M & Retired & $\mathrm{AU}$ & $\mathrm{AU}$ & 1 \\
\hline $\mathrm{P} 16$ & 58 & $\mathrm{M}$ & Manager & SCOTLAND & $\mathrm{AU}$ & 1 \\
\hline $\mathrm{P}_{17}$ & 45 & $\mathrm{M}$ & Civil Servant & PORTUGAL & PORTUGAL & 1 \\
\hline $\mathrm{P} 18$ & 29 & $\mathrm{~F}$ & $\begin{array}{l}\text { Medical } \\
\text { Scientist }\end{array}$ & $\mathrm{AU}$ & UK & 1 \\
\hline P19 & 55 & $\mathrm{~F}$ & Housekeeping & $\mathrm{AU}$ & $\mathrm{AU}$ & 1 \\
\hline $\mathrm{P}_{20}$ & $50-55$ & $\mathrm{M}$ & Retired & $\mathrm{AU}$ & AU & 1 \\
\hline$P_{21}$ & 39 & $\mathrm{M}$ & Travel Agent & UK & UK & 1 \\
\hline $\mathrm{P}_{22}$ & 24 & $\mathrm{~F}$ & Finance & $\mathrm{AU}$ & UK & 2 \\
\hline $\mathrm{P}_{23}$ & 26 & $\mathrm{~F}$ & Unemployed & CANADA & CANADA & 2 \\
\hline $\mathrm{P}_{24}$ & 30 & $\mathrm{~F}$ & Civil Servant & $\mathrm{NZ}$ & UK & 1 \\
\hline $\mathrm{P}_{25}$ & 25 & $\mathrm{M}$ & Engineer & $\mathrm{AU}$ & UK & 1 \\
\hline $\mathrm{P}_{26}$ & 28 & $\mathrm{~F}$ & $\begin{array}{l}\text { Radiation } \\
\text { Therapist }\end{array}$ & $\mathrm{AU}$ & UK & 1 \\
\hline $\mathrm{P}_{27}$ & 27 & $\mathrm{~F}$ & Unemployed & $\mathrm{NZ}$ & $\mathrm{NZ}$ & 1 \\
\hline $\mathrm{P}_{28}$ & 25 & $\mathrm{~F}$ & Health Sector & $\mathrm{AU}$ & UK & 1 \\
\hline
\end{tabular}




\begin{tabular}{|c|c|c|c|c|c|c|}
\hline Participant & Age & Gender & Occupation & Nationality & $\begin{array}{l}\text { Country of } \\
\text { Residence }\end{array}$ & $\begin{array}{l}\text { Frequency of } \\
\text { Visit }\end{array}$ \\
\hline P29 & 44 & $\mathrm{M}$ & $\begin{array}{l}\text { Treasury and } \\
\text { Credit Risk } \\
\text { Manager }\end{array}$ & TURKEY & TURKEY & 2 \\
\hline $\mathrm{P}_{30}$ & 60 & M & Worker & TURKEY & BELGIUM & 1 \\
\hline $\mathrm{P}_{31}$ & 39 & M & Artist/Director & TURKEY & TURKEY & 5 \\
\hline $\mathrm{P}_{32}$ & 33 & $\mathrm{~F}$ & Sales Chef & TURKEY & TURKEY & 1 \\
\hline$P_{33}$ & 35 & M & Representative & TURKEY & TURKEY & 1 \\
\hline $\mathrm{P}_{34}$ & 33 & M & Chef & TURKEY & TURKEY & More than 1 \\
\hline$P_{35}$ & 44 & M & Civil Engineer & TURKEY & TURKEY & 1 \\
\hline $\mathrm{P}_{36}$ & 35 & $\mathrm{~F}$ & Housewife & TURKEY & GERMANY & 1 \\
\hline$P_{37}$ & 37 & M & Driver & TURKEY & GERMANY & 1 \\
\hline $\mathrm{P}_{3} 8$ & 29 & M & Teacher & TURKEY & TURKEY & 2 \\
\hline$P_{39}$ & 56 & F & Retired & TURKEY & TURKEY & 1 \\
\hline $\mathrm{P}_{40}$ & 53 & F & Housewife & TURKEY & TURKEY & 1 \\
\hline $\mathrm{P}_{41}$ & 56 & $\mathrm{~F}$ & Teacher & TURKEY & TURKEY & 5 \\
\hline $\mathrm{P}_{42}$ & 33 & M & $\begin{array}{l}\text { Self- } \\
\text { employment }\end{array}$ & TURKEY & TURKEY & 2 \\
\hline $\mathrm{P}_{43}$ & 29 & M & Worker & TURKEY & TURKEY & 1 \\
\hline $\mathrm{P}_{44}$ & 35 & M & Director & TURKEY & TURKEY & 1 \\
\hline
\end{tabular}

Reliability of the Research

In order to increase the internal reliability of the study, the process of data coding was conducted by two researchers. After the coding process was complete, the coefficient of consistency was calculated using Kappa analyses. The arithmetical average of the Kappa coefficient was found to be $77.8 \%$, which proved that consistency was at a significant level. In order to ensure the external reliability of the study, all of the data collection tools, raw data, coding, interview and observation notes were submitted for supervision and confirmation by an independent expert.

Voice recording was used during the interviews and the recordings were then transcribed into written text. The next phase involved analysing the transcriptions through an inductive content analysis. The data coding process was conducted by two researchers, after which, two main themes - motivation and experience - and supporting categories were obtained.

\section{Findings}

An analysis of the data revealed that the participants who visited the Gallipoli Peninsula Historical National Park were influenced by different types of motivational factors, both pull and push. The motivations of both domestic and international visitors reveal differences between them, but also some similarities.

Upon examination, the findings of this study show that the factors that motivate tourists to visit the Gallipoli Peninsula can be grouped in two categories, namely push and pull motivational factors. These categories consist of nine themes between them. The themes in the pull motivational factors category are: education/learning, history knowledge/awareness, participation in commemoration event and becoming a nation state and cultural identity. The push motivational factors category, on the other hand, include: family ties, curiosity, patriotism, desire to know a different culture, media and reference group. 
When the motivations of the participants are evaluated, it is clear that they consist of both push and pull motivation factors.

Just as with the dark tourism motivations of tourists visiting this area, it emerged that the experiences of the tourists in this study have some differences and similarities according to their nationalities. The findings could be grouped into two categories, psychological and socio-cultural experiences, with six different themes included in these categories. The psychological experiences category consists of four themes, namely, emotional experience, sadness, developing empathy, and memorable tourism experience, while the socio-cultural experiences category consists of two themes, namely, learning/understanding history and nation-state consciousness and cultural identity. In the following section, the motivation and experience themes and categories that emerged are explained under these headings with direct quotations from interviewees.

\title{
Motivations of Tourists visiting Dardanelles
}

While dark tourism motivations may depend upon the reasons of individual tourists, at the same time they can be explained by the characteristics of the destination (Isaac and Çakmak, 2013). The findings of this study show that the motivations for visiting battlefields in the Gallipoli Peninsula are heterogeneous. It emerged that the participants visited the Gallipoli Peninsula Historical National Park due to both push and pull motivational factors.

\section{Pull Motivational Factors}

\section{Education/Learning}

Education is seen as one of the motivations tourists have for visiting places where tragic and often violent incidents have taken place (Cohen, 2011; Farmaki, 2013; Preece and Price, 2005). Similarly, education comes to the fore in the literature, as the most important motivational factor for visiting battlefields (Baldwin and Sharpley, 2009; Henderson, 2000; Leopold, 2007). Education emerged as a sub-theme of the motivational factors held by several of the local tourists that participated in this study, as seen in the opinions below:

\begin{abstract}
Dardanelles martyrs' cemetery is a place I wanted to see, definitely. Here are my daughters, I took them along for them to see under what conditions this country was established, how people lost their lives in order to save this country, what kind of events took place [...] Children too... we are lucky for this matter, we want them to know that. That's why we came here. (Participant 29)
\end{abstract}

Actually, we come here with our children. We want to tell our children what happened here, impress the spirit of this place upon them to some extent... (Participant 35)

\section{[...] we came out to teach our volunteers about the Gallipoli campaign. (Participant 6)}

Education, the most important motivation factor for visiting battlefields, can also be considered the most important source of motivation for the Gallipoli Peninsula, which is a typical example of a battlefield destination. This is supported by previous studies (Dunkley et al., 2011; Kokkranikal et al., 2015; Winter, 2011b).

Knowledge/Consciousness of History

The historical value of the Gallipoli Peninsula is important for both sides in the conflict, Turks, Australians and New Zealanders, in different ways (Prideaux, 2007). As WWI came to an end, Turks, Australians and New Zealanders gained recognition as their respective homes became nation states; this 
emphasizes the importance of the historical interest in the region as it symbolises, to a certain extent, the beginning of a new historical era. In terms of its historic importance on an international level, it is one of most visited battlefields in Europe (West, 2008). In this context, consciousness and knowledge of the historic significance of the location, and a desire to increase their knowledge, was another exogenous motivational component for both domestic and international tourists, as can be seen in the participants' statements below.

Definitely historical. Leading role [motivation] is historical. A war took place here; to relive those days, our elders becoming martyrs here, riding my bicycle here, this was my aim. These were the reasons I had. These made me come to Dardanelles and stay in Dardanelles. Not really for a touristic purpose. (Participant 38)

[...] Nowadays, nationalistic feelings are no longer prominent. They [the new generation] are not brought up with these feelings. We wanted them to get a feel for that era a little bit, feel some things about our country, and remember these things when they are growing up. Maybe we do not feel the history of our country, under what circumstances it was established, how valuable it is, that it is as valuable now as it was in the past. We should feel it a little bit now, as should they. (Participant 35)

The independence of Turkey, our martyrs. Because it is important in a historical sense. (Participant 36)

Conscious visits to this place are an important experience for understanding history, for drawing lessons from history. (Participant 31)

[...] the history, and also I think most Australians having the opportunity to go to Gallipoli. It's just very important [...] I want to know about history. (Participant 1)

I think to learn, to learn more. I've learned so much about history, ... (Participant 9)

just because of our history - our war history and those that gave everything years ago for our freedom...I just wanted to see where it was... and what it was [in the past]... (Participant 15)

[...] definitely history and Anzac Dawn Service. (Participant 27)

[...] because I love history and military history also attracts me ... (Participant 17)

After evaluating the participants' opinions on the knowledge/consciousness of history motivation, it can be said that one of the motivations of both domestic and international tourists for visiting this region emerges as a desire to gain historical knowledge and develop historical consciousness by travelling to sites where incidents occurred in the past (Kokkranikal et al., 2015; Preece and Price, 2005). It is possible to attribute this to the Turkish Australian, and New Zealander tourists who visit the region.

\section{Participation in Commemoration Ceremonies}

Another factor that has been suggested as the most important motivation for visiting battlefields in the context of dark tourism is a desire to participate in commemoration ceremonies (Baldwin and Sharpley, 2009). Ceremonies that commemorate those who lost their lives on the battlefield are held at 
mausoleums that were built after the battle with the purpose of strengthening national identity or remembering the establishment of a nation state, as well as, of course, to remember and pay respect to previous generations who lost their lives there (Farmaki, 2013; Hyde and Harman, 2011; Kokkranikal et al., 2015).

Just the feel of the place, such active emotions, and obviously the commemoration ... For us, it is like pilgrimage for Australians to go there and do the remembrance... So we go there and we remember the exmodalized the victory... (Participant 4)

Anzac Day - the services at Gallipoli [...] to pay tribute to the fallen soldiers in the past. (Participant 5)

So, main reason to come to Anzac is because we celebrate Anzac Day every year in Australia... (Participant 13)

\section{[...] to commemorate our soldiers [in] the ceremony ... (Participant 16)}

I'm here to experience what other Australians have done before me. So, it's something that every young Australian wants to do and I think needs to do, so that's my motivation for coming over here and witnessing what happened and experiencing things first hand. (Participant 11)

\section{[...] to commemorate everything they did for us.... (Participant 22)}

From the participants' opinions given above, it is clear that many of the participants were visiting the region with the primary motivation of attending and/or wanting to experience the ceremony organized for Anzac soldiers. It can also be said that the reasons for this motivation are the spiritual feelings of the Australian tourists towards the memory of Anzac soldiers who lost their lives during the war, and the respect and gratitude they feel towards them. In this context, the views expressed above by the participants in terms of their motivations for joining commemoration activities are supportive of the thesis put forward by related studies that argue this is one of the real motivations of Australian and New Zealander tourists visiting the Gallipoli Peninsula (Dore, 2006; Hall et al., 2010; Prideaux, 2007; Ryan, 2007b).

Becoming a Nation State and Cultural Identity

National identity and culture consciousness have emerged as another motivational component in this study. As indicated in previous sections, after WWI, the Gallipoli Peninsula became important for Australians and New Zealanders in the context of becoming a nation state and consequently, gaining national identity; the Gallipoli Peninsula is equally important for Turks for similar reasons (Basarin et al., 2010).

So, after the World War, we [had] just been born as a nation. So, we were 1901; so, Gallipoli was 15 years later; so it was very early for us. So yes, it is like the birth of a national identity... (Participant 4)

It [Gallipoli] is a big part of our national identity. (Participant 25) 
Another motivation of the participants for visiting the Gallipoli Peninsula refers to the emergence of the nation state and cultural identity. The opinions stated by the participants regarding this aspect of their history shows that the establishment of their nation state and the consequent development of a cultural identity, and the role of the battle in that process, makes the battlefields of the Gallipoli Peninsula important places for Australians and New Zealanders (Hall et al., 2010; Slade, 2003). Another important point to be emphasized is that for Australians and New Zealanders who visit the region in a secular rather than a religious context, it is seen as a cultural and historical pilgrimage (Basarin et al. 2010). The statements of some of the participants seem to support this.

\section{[...] Muslims have Mecca. We have Gallipoli. (Participant 1)}

It is not religious for us. [...] It is something different [...] It is a part of Australian history. So, it is a historical pilgrimage. [...] And maybe that's what pilgrimage is. It is a historical pilgrimage; it is the birth of our identities as Australians. And for New Zealanders, the same. It is how we express ourselves. (Participant 4)

\section{[...] there is no pilgrimage in the religious sense at all. (Participant 21)}

The views of the participants who see their visits to the battlefields of the Gallipoli Peninsula as a secular pilgrimage due to the symbolic importance of the war for the formation of their nation state and the development of their cultural identity are supported by other research (Hall, 2002; Hyde and Harman, 2011; Kokkranikal et al. 2015; Seaton, 2002). The importance attributed by Australian and New Zealander tourists to the Gallipoli Peninsula may also be explained by the interpretations of different groups or persons in terms of the spiritual qualities of the region (Foley and Lennon, 1996a). As a result, when the travel motivations of Australian, New Zealander and domestic tourists to the region are examined, the symbolic value of the region is observed to arise mostly from the fact that each of these countries became nation states after the battle took place (Ryan and Cave, 2007; Yeneroğlu-Kutbay and Aykaç, 2016). Visits made to the region are being shaped by the motivation to strengthen one's national identity (Farmaki, 2013).

\section{Push Motivational Factors}

Family Ties

Previous studies have indicated that motivations to visit the Gallipoli Peninsula depend upon several factors, one of which relates to relationship ties between tourists and individuals who lost their lives during the battle (Hyde and Harman, 2011). It is clear that this motivational factor constitutes one of the sources of motivation among the visitors who participated in this study.

I am, of course, interested [in] where my father fought. Yeah, it is a family member... My father, although he fought the Turks, was very respectful of them... We've tried to follow where they went, where they fought and those that were killed. We've visited their graves. (Participant 7)

[...] main reason, I think, that motivated me to come to Istanbul and Turkey is because of the Anzacs, because I've got my grandfather... he fought for Australia and then I've got lots of great, great uncles that fought in Gallipoli. (Participant 18) 
[...] I wanted to come here because our great-grandfather was martyred here. [...] Actually I couldn't find his grave but I would like to think, imagine and feel how they fought here, I mean. I came for this reason. (Participant 38)

[...] My grandfather also participated in that war. He used to tell us he had fought in this battle... Since those were our feelings since childhood, I wanted to see this place. (Participant 39)

When these statements are considered, it is clear that having family members who were involved in the war is a decisive motivational factor for visiting the region (Kokkranikal et al., 2015). An examination of the countries of origin of the participants who expressed this motivation for visiting the region reveals that they were all citizens of either Turkey, England or Australia; this is an important point to note.

\section{Curiosity}

Another motivation for visiting battlefields, which arises alongside empathy, is curiosity (Isaac and Çakmak, 2013; Ryan, 2007b). Curiosity emerged as another motivational component in this study.

It was for travel. I was wondering about this place (Gallipoli Peninsula). My friends also suggested it. So, we went for a few days. (Participant 32)

Because of curiosity... My brother-in-law also came here. Some of my friends also came. They told me, "You should come and visit". (Participant 37)

People are curious about how the Dardanelles War broke out. People are curious. I mean, how did our elders go [to fight]? People are curious about how it really happened, how it ended, how they fought. They would like to see [the location] for real. I also came to see it for real. (Participant 43)

[Just curious about the history] interest [in] the history, in this case it was [the] Gallipoli battle... (Participant 17)

In the context of dark tourism and visits to places where many people have died, the literature reveals that curiosity is often highlighted as the main motivation source (Isaac and Çakmak, 2013; Ryan, 2007b). However, this motivational factor has not emerged in previous studies of battlefield tourism, which is a form of dark tourism. Slade (2003) and Hall et al. (2010) argue that the motivation sources of tourists that visit the Gallipoli Peninsula do not arise from curiosity; on the contrary, these places are visited because they carry symbolic value as a place where nation states were born. Yet, in this study, curiosity was mentioned by one of the participants as their motivation for visiting the region.

\section{Patriotism}

The Gallipoli Peninsula, a site of historical importance, is known among Turks, Australians and New Zealanders as a place that has spiritual value as it constitutes the beginning of the formation of their respective nation state identities (Ryan, 2007a). Although on the losing side, participation in annual commemoration ceremonies has symbolic value for Australians and New Zealanders, as it does for Turks, who were on the winning side (Prideaux, 2007). The data obtained from the interviews in this study revealed a motivation for visiting the region for the purpose of commemoration for Australians, whereas for local tourists, they were commemorating those who lost their lives during the war. This 
motivation to visit martyrdoms and mausoleums, which are regarded as sacred, can be explained in relation to the concept of patriotism.

\author{
Patriotism, the history... (Participant 1) \\ Patriotism and just kind of respect, the Australian history... (Participant 2) \\ Patriotism. And I think it's something that everyone, every Australian should do to come \\ here and to see how hard it was for the men and all of that. (Participant 3) \\ Patriotism, and to pay tribute to the fallen soldiers in the past... (Participant 5) \\ [...] it is a family member; patriotism and we're interested in both. (Participant 7)
}

The concept of patriotism as a direct reason for travelling to the region was primarily mentioned by the Australian participants. The most important aspect of this patriotism that emerged were references to the heroism of those who lost their lives fighting for their country during the war (Kokkranikal et al., 2015; Ryan, 2007a).

\title{
Desire to know a different culture
}

The desire to know different cultures emerges as a factor in the motivation to travel to places where battles have taken place for tourists interested in battlefield tourism, in the context of dark tourism (Bigley et al., 2010). This factor, the desire to know a different culture, was mentioned by the participants of this study, particularly the Australian participants, in relation to their motivations for visiting the Gallipoli Peninsula.

Obviously I've seen a lot of pictures, and umm it just looks like an amazing place, and just experiencing another culture. (Participant 18)

\section{[...] Culture, something different and Anzac Day. (Participant 3)}

[...] So, I would say that, it is particularly related to Gallipoli. If you would say like Istanbul, I would say that we wanted to go to Istanbul because of the culture. So, we wanted to experience the Turkish culture. (Participant 4)

Unlike some of the other motivational factors discussed, this motivational factor emerged, not as a motivation to travel for its own sake, but rather as one of several motivational factors mentioned by the participants. This was often because several of the international participants' visits included not only a visit to the Gallipoli Peninsula, but also touristic trips to other parts of the country, sometimes before visiting this region and attending the commemoration ceremony and sometimes afterwards.

\section{Media}

The role of the media in the formation of tourists' motivations to visit destinations developed alongside its role in the emergence and development of the concept of dark tourism; roles which also, as stated in previous sections, emerged in this study (Foley and Lennon, 1996a; Seaton, 2002; Sharpley, 2005). In this context, it can be said that the media played a role in creating and encouraging both the push and pull motivational factors for visiting the battlefields located at the Gallipoli Peninsula Historical National Park among the tourists in this study. The media sources in question include traditional media channels as well as some popular social media outlets that have emerged with the development of technology. The findings of the research have revealed the different ways in which the media influenced the travel motivations of the tourists visiting the region, as seen in their statements. 
I would have to go and say social media. '[...] but also what we were taught in school... (Participant 1)

Internet. Yeah! Social media. (Participant 5)

Of course. We can say. Because of the $100^{\text {th }}$ Anniversary there was the Russell Crowe movie [...] Therefore, for the $100^{\text {th }}$ Anniversary celebration showing in [the] mass media there was a lot about Gallipoli ... (Participant 21)

In Turkey... there was a broadcast about the renovation of monuments and memorials in this area and an initiative to increase awareness of it. After I watched it, I was very impressed. (Participant 30)

[...] Social media is everywhere [...] Particularly when we were passing Gökçeada it was very effective. Suggestions there: recommendations such as 'you should come and stay here [...] don't go before seeing that' were effective. (Participant 34)

It was effective. There is a Gallipoli movie. You are impressed when you watch it. How did they fight, with what weapons did they fight?... A different feeling. Very different... (Participant 37)

[...] I always thought about coming to Dardanelles [...] But I think I watched all the movies. Movies have motivated me more than other things. (Participant 38)

In light of the statements provided above, it is clear that the findings support the view that the media has a very important role in the process of disseminating information about the region, which strengthens both domestic and international tourists' motivations for visiting the region. This concurs with the findings of other studies and demonstrates that the media has a significant impact on dark tourism motivations (Foley and Lennon, 1996a, 1996b; Yuill, 2003).

\section{Reference Group}

Some of the participants who visited the Gallipoli Peninsula mentioned that another factor that helped generate the motivation to travel to the area was propaganda through word-of-mouth from reference groups (relatives, friends, etc.).

I have friends who have been here before and they said that there were very pleasant and emotional things... (Participant 27)

\section{[...] Mainly, Mom and Dad ... (Participant 3)}

A lot of friends influenced us. They've been here before. We've had friends been here before and they have encouraged us to come ... (Participant 8)

Social media didn't have any role in us coming here. [...] Friends, family... (Participant 19)

Family and friends. The main effective factor was family and friends sharing stories with us about their visits to the region. (Participant 32) 
[...] There was no specific thing affecting me apart from our friends who came here before.

We know that they were impressed as well... (Participant 35)

Following an evaluation of the statements above, it is possible to say that information obtained from close reference groups (relatives, friends, etc.) who had already visited the region played an effective role in generating a motivation to visit the Gallipoli Peninsula among the participants. This suggests that although the media can be an effective factor in generating travel motivations, reference groups can also impact people's motivations to visit tourism destinations (Kaya, 2006; Murphy et al., 2007).

\section{Tourism Experiences of Tourists Visiting the Gallipoli Peninsula}

Alongside dark tourism motivations, the experiences of tourists to this region were also examined in this study, and revealed similarities and differences according to the nationalities of the participants. Dark tourism, in terms of the experiences it provides, differs from other cultural experiences (Yeneroğlu-Kutbay and Aykaç, 2016). The findings of this study are set forth in two categories, psychological and socio-cultural experiences; within those categories are included six different themes. The psychological experiences category consists of four themes, namely emotional experience, sadness, developing empathy and memorable tourism experience. The socio-cultural experiences category consists of two themes, namely learning/understanding history and nation-state consciousness and cultural identity.

\section{Psychological Experiences}

Emotional Experience

In this first category, the emotional aspect of the experiences that the participants had during their visits emerged as the sub-theme most frequently mentioned by the participants. The experiences of both domestic and international tourists of visiting the site were similar and included emotional reflections upon the war that took place there.

There was information between the lines of the books we read, but the things that were told [to] us by the tour guides during our tour [...] knowing those [things] affect people more [...] Therefore, when you look at it from our point of view, from my country's point of viewstepping outside the historical reality- my feelings come into prominence. (Participant 29)

When you visit the region without other visitors, it is really very impressive... (Participant 31)

There are really many impressive things [...] I can say that self-devotion was the emotion that was mostly felt, [that] emerged as a prominent concept here... Of course there is an emotional part to this war. (Participant 35)

It is completely different. You turn the clock back. You feel that you lived those events. It is a completely different thing. It is an effect which is more emotional. (Participant 36)

[...] It was very similar but you just don't get the same sense that you do here, it's a bit more touching. It's like really, really moving. (Participant 18)

I think the factor of services at Dawn is quite emotional. Because as they [are] doing the speeches in the presentations, [it] is very, very dramatic. (Participant 21) 
[...] they're very emotional. It's very hard to comprehend some of the, you know, the details and the graves and things like that. Makes you feel like a bit teary ... (Participant 2)

The participants' statements concerning their experiences of visiting the Gallipoli Peninsula battlefields suggest that both the domestic and international tourists had similar emotional experiences. These findings provide further evidence of the emotional experience characteristic indicated in the literature on dark tourism experiences (Kang et al., 2012; Yeneroğlu-Kutbay and Aykaç, 2016).

\section{Sadness}

The second most-frequently expressed effect, after emotional, described by the participants who visited the Gallipoli Peninsula battlefields, was sadness. In this study, it became clear that the experiences of both domestic and international tourists were solemn as most of the feelings expressed by them were negative.

Very emotional, sad, sadness, yeah, I think. (Participant 1)

Sadness and pride! Sad, because so many people died and they were young but pride because they kept fighting, they didn't give up. (Participant 3)

[...] it's quite sad to think, like how many lives were lost... (Participant 18)

A lot of sadness, with all the lives that were lost ... (Participant 19)

How sad it was for Australians? (Participant 20)

[...] When I visited the martyrs' cemeteries and thought about the people who lost their lives for their country, I felt sad... (Participant 38)

The experiences gained by both the domestic and international participants during their visits to the area were solemn; this is a second sub-theme that emerged during the course of the research. The most important factors that generate this sadness are tourists' perceptions of the area as it is presented to them and their emotional interpretation of the site (Miles, 2002).

\section{Developing Empathy}

Developing empathy is another factor that gives form to the experiences of visitors to the Gallipoli Peninsula Battlefields. This factor became prominent in the study, either directly or indirectly, as another experience component gained by the participants during their visits. As well as asking questions with the aim of understanding their experiences of visiting the area, the study also asked "Can a sense of developing empathy explain your feelings?" The participants' comments were:

Of course! Feelings of empathy [...] We all read, heard about it in books, and we were always told to see this for real [...] Again, we received some information from our guide but it is a very different feeling to seeing the places where the events took place... (Participant 29) Yes, we can say that. We can say that it is empathy. We can say that we developed empathy. We can say that this means to live that moment by going back to the past and to put ourselves in their place. (Participant 38)

[...] It created an impression that people fought for their country in the past with their hearts and souls. I felt empathy. (Participant 30)

You really get very affected [...] Our lives are easy but if you think about how they lived in the past, your mind is blown. (Participant 37) 
[...] the emotion I felt at the ceremony [...] trying to convey the difficulties that these, these soldiers - these soldiers faced... (Participant 16)

Just how big the space was and how hilly it was and just looking at perspectives from both sides... (Participant 9)

[...] I mean it's quite surreal seeing all the trenches, and everything like that, and it's quite sad to think, like how many lives were lost [...] Turks, Australians, New Zealanders. But I think the most important thing that I got from the whole experience was that... (Participant 18)

I think it was just an overall surreal experience actually being back where all that happened so long ago. And just trying to imagine what it would have been like, and I was just camping out in the area as well experiencing the cold and being without everyday things that we take for granted. (Participant 26)

Developing empathy is generally known as one of the motivational factors of those interested in dark tourism (Ryan, 2007b). In this study, it also has the characteristic of being a component that emerged under the experience theme. Developing empathy was put forward as an emotion expressed directly by domestic visitors and as an experience factor expressed indirectly by international tourists. Developing empathy, in the context of dark tourism, is an element that can be formed when comments are made by tourists about areas they visit and museums in those areas (Miles, 2002). As a result, it can be said that the empathy developed towards the area of the Gallipoli Peninsula battlefields by tourists appeared as a reflection of the interaction process and a product of the psychological process (Sharpley and Stone, 2009; Stone, 2009).

\section{Memorable Tourism Experiences}

Another important sub-theme that emerged from the findings is the memorable tourism experience as a form of emotional experiences. The tourism experiences that relate to this sub-theme came into prominence most significantly in replies to the question "Which were the factors that made your visit memorable?", in quite different ways depending on whether they were domestic or international tourists. The participants made the following statements about the emotions obtained and those that were imprinted most strongly in their memories following their visits to the battlefields of the Gallipoli Peninsula.

[...] there was one very memorable one. It was from a Turkish soldier. And the Turkish soldier he wrote a letter to his mother and father. Look after my wife, look after my child... very emotional. (Participant 1)

Gallipoli is a memorable experience. I would just tell particularly about Gallipoli, about the emotions and the remembrance. (Participant 4)

Just how big the space was and how hilly it was and just looking at perspectives from both sides ... (Participant 9)

...to be honest we all sort of felt that the New Zealand ceremony was very, very touching. Had lot of cultural events, had lot of singing and the haka at the end was just unbelievable... (Participant 10) 
...the memorable spots up at Gallipoli and the wonderful people of Istanbul and here [Gallipoli] will all stay in our minds forever I think. (Participant 19)

I think the New Zealand service. It was magical, powerful, humbling, moving, inspiring. (Participant 21)

In my opinion, what Atatürk had said in memory of Anzac soldiers [that is written] on our monument is very important. (Participant 29)

The martyrs' cemetery, for example, is an unforgettable memory for me... (Participant 32) Actually, what we were told here made it unforgettable... So what we were told by friends, people here strengthened the impression on us... (Participant 35)

Martyrdom is always on my mind. Our people, who gave their lives, sacrificed [their lives] and so our ancestors should not be forgotten. One must see and feel here... (Participant 39) Prayer Bastion. The short films shown there and their sounds impressed us a lot. I can never forget it (Participant 36)

In light of the statements above, it can be said that the elements that made their experiences memorable were the feelings that their visits to the area evoked in them. The tourists who participated in the study stated that the touristic elements that evoked particularly strong feelings were the monuments, martyrs' cemeteries, inscriptions and memorials located at the site.

\section{Socio-Cultural Experiences}

Learning/Understanding History

In previous sections, interest or curiosity in history and learning history were the most important motivation given for travelling to destinations related to dark tourism (Kokkranikal et al., 2015; Preece and Price, 2005). The findings of this study demonstrate that learning and understanding history are at the forefront of the experiences gained by both local and foreign tourists visiting the Gallipoli Peninsula battlefields, as the participants discussed the films and documentaries they watched during the commemoration ceremony and the historical memorials and inscriptions they saw at the site.

Yeah, history and where actually things happened and why they happened. Because we only seem to get taught a very brief history ... (Participant 2)

[...] I've learned so much. About history, yeah, it's really changed my perspective on it. (Participant 9)

[...] we watched a lot of documentaries about this site...I think [they] gave us a really deep understanding of what happened here. (Participant 6)

[...] I think it just gives you a better understanding of the whole situation... (Participant 15)

[...] I think it gave me a deeper understanding of that history [...] we went to the Turkish memorial, and we went to the 57th Regiment Memorial. So, it's just understanding the impact that the war had on both countries. (Participant 16)

The documentaries were very important. They gave me more knowledge, and a more, bigger understanding of the war ... (Participant 1) 
[...] If made consciously, visits to this place are important experiences in order to
understand the history and to take lessons from it. (Participant 31)

I can say that our bonds with history are tighter now. It has strengthened our ties with the past (Participant 34)

An examination of the views of the participants reveals that a consciousness has been formed to an important extent in terms of providing historical information to visitors interested in history. An impression was also gained from the face-to-face interviews with the participants that they were given important historical knowledge during the visit. Undoubtedly, the role of the tours led by guides should be seen as another important aspect of visitors' learning and understanding history.

\section{Nation-State Consciousness and Cultural Identity}

Another experience dimension derived from the data obtained in this study is nation-state consciousness and cultural identity. This was mentioned by the study's participants as one of the factors that formed their travel motivations. The symbolic value of the Gallipoli Peninsula battlefields for citizens of both Australia and New Zealand is the acquisition of a cultural identity that was formed during the processes in which their respective nations became nation states (Slade, 2003). In this context, the main elements that make visiting the site meaningful for Australians and New Zealanders are the nation-state consciousness and cultural identity components.

I always wanted to explore what people meant by the Anzac spirit and I think coming here, we got a real good understanding what it meant to be an Anzac and how that helped us to develop as a nation. (Participant 10)

\section{[...] you know it's got to do with freedom, liberty and our national identity. (Participant 4) \\ [...] I think it's worth it to celebrate this kind of key point in the history of a nation - it should not be forgotten. (Participant 17)}

[...] What we call our country's defence was achieved through the sacrificing of lives. Actually, this is the most impressive part. You can see what kinds of things people sacrificed in order to defend this country and freedom... (Participant 35)

When these views are taken into consideration, the importance of the Gallipoli Peninsula battlefields for Turkish, Australian and New Zealander tourists comes to the forefront as a location that was significant in the formation of their respective nation states and cultural identities. This finding concurs with the results of previous studies (Basarin et al., 2010; Donoghue and Tranter, 2015; Prideaux, 2007; Yeneroğlu-Kutbay and Aykaç, 2016).

\section{Conclusion}

An examination of the travel motivations and experiences of tourists who have visited the battlefields located at the Gallipoli Peninsula Historical National Park has revealed that there are similarities and differences according to the nationalities of the visitors. Although these findings concur with the findings of previous studies, they also include results that reflect the uniqueness of the study's context. While dark tourism motivations may depend on tourists own personal reasons for visiting a destination, they can also be explained with reference to the special characteristics of the destination in question (Isaac and Çakmak, 2013). Research has shown that tourists' motivations for visiting the battlefields of 
the Gallipoli Peninsula have a heterogeneous structure. The analysis undertaken in this study has revealed that the participants visited the Gallipoli Peninsula Historical National Park due to different types of push and pull motivational factors. While the motivations of both the domestic and international visitors who participated in this study had some similar characteristics, there were also some key differences. The factors that motivate tourists visiting the site in the context of dark tourism can be grouped into three categories, namely, push, pull and both push and pull motivational factors.

In this context, motivations can be grouped into two categories and ten themes. The themes included in the attracting motivational factors category are: education/learning, history knowledge/ consciousness, participating in a commemoration ceremony and becoming a nation state and cultural identity. In the push motivational category, there are the following themes: family ties, curiosity, patriotism, desire to know a different culture, media and reference group. It is clear that both internal and external motivational factors affected both the domestic and international tourists who participated in this study, in their visits to the region.

The experiences of tourists who have visited the region in question show similarities and differences in terms of dark tourism motivations, according to their nationalities. Dark tourism differs from other cultural experiences in terms of the experiences it offers (Yeneroğlu-Kutbay and Aykaç, 2016). The findings obtained in the study were grouped into two categories, known as psychological experiences and socio-cultural experiences, with several different themes included in these categories. The psychological experiences category included four themes: emotional experience, sadness, developing empathy and memorable tourism experience. The socio-cultural experiences category included two themes: learning/understanding history and nation-state consciousness and cultural identity.

Curiosity and a desire to know different cultures were stated as travel motivations by the participants in this study; this differs from the results obtained from similar studies. The most significant travel motivations mentioned by the Turkish participants were education/learning and knowledge /consciousness of history, whereas for the Australian and New Zealander tourists, participation in commemoration ceremony was the most important motivational factor. This is in line with the findings of other studies conducted examining the motivations of tourists from Australia and New Zealand (Hyde and Harman, 2011; Lagos et al., 2015; Prideaux, 2007).

When the tourism experiences of the participants are evaluated, it is clear that the most significant common aspect of their experiences was the emotional and saddening impact of their visits. In other words, the experiences that visitors have are formed by their psychological and emotional interactions with the locations visited, including those where commemoration ceremonies are held (Cohen, 2011). The experiences that the participants had during their visits may be impacted by either their individual psychological characteristics or socio-cultural characteristics. In addition, the historical and cultural characteristics of the destination are important. For Australian and New Zealander tourists, participation in commemoration ceremonies emerged as an important ritual for their understanding of their own cultural identity. This is similar to the experiences of Turkish people visiting the site.

Another aspect was revealed as making the experiences of both domestic and international tourists who visit the Gallipoli Peninsula battlefields impressive, namely, the authentic design of the site and the importance of the places open to tourists. In this context, visits to the site area in question, visitors' interpretations of the site during and after commemoration ceremonies, their interactions with the knowledge gained during the visit, and the development of their learning level and environmental 
perception lead to positive experiences. These findings are supportive of other studies in the literature (Chang, 2014).

Another important finding of the study is that both conventional and social media have an effect on tourists' motivations to visit the site in question, acting as a push factor. Other studies have demonstrated how media and information acquired before visiting a tourism site play a decisive role in the experiences of some visitors (Liyanage et al., 2015; Yuill, 2003).

When the motivations and experiences of tourists who visit the Gallipoli Peninsula battlefields were examined, it is clear that they were in line with other studies carried out on special interest tourism that mostly depends on culture (Kozak and Bahçe, 2012; McKercher, 2002; Minic, 2012). It was also observed that the participants reflected a multi-purpose cultural type of tourist rather than simply a cultural tourist type.

The findings from the study show that the battlefields located at the Gallipoli Peninsula Historical National Park can be categorized as the "darkest” type of dark tourism, according to Stone's (2006) dark tourism shading scheme. In this context, the authentic positioning of the site, its high political effect and ideology, the fact that it is education-focused and history-centred, and is seen as authentic, as well as the fact that visits to the site tend to be of a short duration, the site is not oriented towards supply and has less infrastructure were all supported by the findings obtained from the participant observations.

In terms of experience types, the dimensions of the experiences that the visitors had can be said to be closer to the emotional and informative experience category. This supports the emotional and informative experiences approach developed by Aho (2001). The study also revealed that the experiences the participants had during their visits included some of the positive and negative characteristics proposed by Pearce and Caltabiano's concept of experience components (1983). While the sadness expressed by the participants was primarily seen as a negative emotional experience, learning about and understanding their history and developing their nation-state consciousness and cultural identity were seen as positive experiences.

The transformation of the Gallipoli Peninsula Historical National Park into a sanctuary was completed after the war when the Gallipoli Campaign took place, and after the five phases developed by MacCannell (1976) were fulfilled; this is similar to the case of the Waterloo battlefield (Seaton, 1999). The importance of the Gallipoli Peninsula Historical National Park is different for Turkish compared to Australian and New Zealander tourists. For Australians and New Zealanders, Gallipoli has a spiritual meaning and, consequently, cultural and secular pilgrimage characteristics come into greater prominence. This may be because it represents the beginning of the formation of their respective nation states and related cultural identity, after the end of the war. In other words, the deaths of Anzac soldiers have symbolic meaning in terms of social belonging, awareness of being a nation state and the formation of a cultural identity that includes moral values such as national independence, patriotism and heroism (Hall, 2002; Hyde and Harman, 2011; Kokkranikal et al., 2015; Ryan, 2007a; Seaton, 2002). In this regard, visits to the area made by Australian and New Zealander tourists can be thought of as secular or modern pilgrimages conducted in a historical and cultural context, as discussed in the dark tourism literature (Collins-Kreiner, 2010a, 2010b; 2016; Stone, 2005), rather than having a religious dimension. This area is perceived differently by Turkish tourists, whose visits to, and interpretation of, the area includes a religious aspect and religious rituals. This difference can also be seen by the fact that different mausoleums and martyrs' cemeteries have different constructional and architectural forms. Different 
interpretations and the attribution of different values to the site by tourists depends on the active role played by cultural identity, developed during the nation-state formation process, alongside the contributions of archaeological sites, which, over time, have gained a cultural dimension, particularly in light of the formation of the nation states in question (Palmer, 1999; Young, 1999).

Studies of the motivations of tourists to visit war sites make it clear that tourists are influenced by more than one motivational factor (Kokkranikal et al., 2015). The travel motivations of both the domestic and international tourists to the Gallipoli Peninsula who participated in this study illustrate these differences. The travel motivations of the Australians and New Zealanders who visited the Gallipoli Peninsula battlefields were mostly participation in a commemoration ceremony (e.g. experiencing a service at dawn), family bonds and recognition of a different culture, whereas historical information/awareness, education/learning, family bonds and interest were the travel motivations of local tourists.

The differences in the experiences gained by the participants can be explained with reference to the different level of psychological and emotional reflection experienced by the visitors, for various reasons, during the communication process with the site where the commemoration ceremony was held, as well as other sites visited (Cohen, 2011). This result supports the view that similar tourism products can generate different experiences (Prentice et al., 1998).

In this study, it was observed that the experiences expressed under the theme of developing empathy show that legendary places that bring to mind patriotism and heroism among tourists are perceived and interpreted differently by members of different societies. The experience approach based on this phenomenon mostly reflects the iconic experience that is contextualized by tourists' gaze upon the relevant site, which contributes to the development of the experience, and its content (Hayllar and Griffin, 2005; Ryan, 2007a; Sternberg, 1999). In other words, it is possible for tourists to obtain these types of experiences that are socially contextualized by means of the beliefs and opinions that they already have (Kokkranikal et al., 2015).

\section{Limitations of the Study}

The above-mentioned comprehensive study was conducted in order to understand the motivations and experiences of tourists visiting the Gallipoli Historical National Park. As the research was conducted on significant dates and in the context of a sample event as part of the research design, the data obtained are limited in terms of time and place and so generalizations are not possible. In addition, due to time constraints, focus group interviews with local and foreign tourists could not be conducted.

Some suggestions are presented for researchers and practitioners with regards to the findings of this study. Studies related to motivation and experience in the context of dark tourism have examined the phenomenon both from the supply-side and the demand-side. The data obtained from this study show that there are some cultural differences which constitute a component that affects both motivation and tourism experiences. Therefore, it would be beneficial for future studies to aim to develop a deeper understanding of the motivations and experiences of tourists who visit the site, from an anthropological perspective.

The results and conceptual classifications (typologies) obtained from previous studies on the dark tourism concept would be valuable in order to present a comparative perspective, rather have more cultural qualifications and studies of the area in a cultural context. In the context of dark tourism, studies examining motivation and experience have physiological and socio-cultural dimensions. 
Therefore, a determination of the dimensions typical to the destinations that affect motivation and experience, in the context of dark tourism, and their effect on motivation and experience should be studied by conducting a relational analysis, which may provide important clues for stakeholders in charge of destination management.

The opinions of tourists visiting the area were evaluated in this study. Future studies may want to focus on measuring local people's tourism perceptions and attitudes. A future study may be conducted to investigate how the attractiveness of destinations can be increased and what steps can be taken to develop tourism across all seasons of the year by using qualitative research methods with tourism stakeholders (face-to-face interviews and/or focus group interviews). Studies measuring the levels of interaction between local people and tourists would be valuable. Studies aiming to understand and/or measure the degree of reflection of some of the authentic characteristics of the site regarding the perception of the related place among tourists visiting the area may also contribute positively to the literature.

\section{Acknowledgements}

The author would like to thank the Akdeniz University Scientific Research Coordinator that supported this project as a PhD Dissertation under Grant No: SDK-2016-1626.

\section{References}

Aho, S. K. (2001). Towards a General Theory of Touristic Experiences: Modelling Experience Process in Tourism. Tourism Review, 56 (3-4), 33-37.

Aliağaoğlu, A. (2008). Savaş Alanları Turizmi İçin Tipik Bir Yer: Gelibolu Yarımadası Tarihi Milli Parkı [A Typical Place to Battlefield Tourism: Gallipoli Peninsula Historical National Park]. Milli Folklor, 20(78), 88-104.

Amujo, O. C. \& Otubanjo O. (2012). Leveraging Rebranding of 'Unattractive' Nation Brands to Stimulate Post-Disaster Tourism. Tourist Studies, 12(1), 87-105.

Auschwitz Report (2014). URL: http://auschwitz.org/en/museum/museum-reports/ (Accessed on 10.11.2015).

Baldwin, F. and Sharpley, R. (2009). Battlefield Tourism: Bringing Organised Violance Back to Life. In Sharpley, R. and Stone, P. R. (eds.) The Darker Side of Travel: The Theory and Practice of Dark Tourism. Bristol: Channel View, 186-206.

Banyai, M. (2010). Dracula's image in tourism: Western bloggers versus tour guides. European Journal of Tourism Research, 3(1), 5-22.

Basarin, J., Hall, J. and Fewster, K. (2010). Anzac Day at Gallipoli: A Turkish Perspective. In Hede, A.M. and Rentschler, R. (Eds), Reflections on ANZAC Day: From One Millennium to the Next. Heidelberg Press: Heidelberg, 65-76.

Bigley, J. D., Lee, C. K., Chon, J. and Yoon, Y. (2010). Motivations for War-Related Tourism: A Case of DMZ Visitors in Korea. Tourism Geographies, 12(3), 371-394.

Biran, A., Poria Y. and Oren G. (2011). Sought Experiences At (Dark) Heritage Sites. Annals of Tourism Research, 38(3), 820-841.

Biran, A., Liu, W., Li, G. and Eichhorn, V. (2014). Consuming post-disaster destinations: The case of Sichuan, China. Annals of Tourism Research, 47, 1-17.

Blom, T. (2000). Morbid Tourism-A Postmodern Market Niche with an Example from Althorp. Norsk Geografisk Tidsskrift-Norwegian Journal of Geography, 54(1), 29-36.

Boateng, H., Okoe, A. F., and Hinson, R. E. (2018). Dark tourism: Exploring tourist's experience at the Cape Coast Castle, Ghana. Tourism management perspectives, 27, 104-110. 
Catalca, H. and Yurtseven, H. R. (2003). Understanding New Anzacs: A Managerial Perspective. Anatolia, 14(2), 127-141.

Chang, T. Y. (2014). Dark Tourism: The Effects of Motivation and Environmental Attitudes on the Benefits of Experience. Revista Internacional de Sociología, 72(2), 69-86.

Cheal, F. and Griffin, T. (2013). Pilgrims and Patriots: Australian Tourist Experiences at Gallipoli. International Journal of Culture, Tourism and Hospitality Research, 7(3), 227-241.

Chen, C. M., and Tsai, T. H. (2019). Tourist motivations in relation to a battlefield: a case study of Kinmen. Tourism Geographies, 21(1), 78-101.

Clark, L. B. (2010). Always Already Again: Trauma Tourism and the Politics of Memory Culture. Encounters, 1, 65-79.

Cohen, E. H. (2011). Educational Dark Tourism at an In Populo Site: The Holocaust Museum in Jerusalem. Annals of Tourism Research, 38(1), 193-209.

Coldwell, W. (2013). Dark Tourism: Why Murder Sites and Disaster Zones Are Proving Popular, The Guardian, October 31. URL: http://www.theguardian.com/travel/2013/oct/31/dark-tourism-murdersites-disaster-zones (Accessed on 06.12.2015).

Collins-Kreiner, N. (2010a). Researching Pilgrimage: Continuity and Transformations. Annals of Tourism Research, 37(2), 440-456.

Collins-Kreiner, N. (2010b). The Geography of Pilgrimage and Tourism: Transformations and Implications for Applied Geography. Applied Geography, 30(1), 153-164.

Collins-Kreiner, N. (2016). Dark Tourism as/is pilgrimage. Current Issues in Tourism, 19(12), 1185-1189.

Conway, B. (2010). New Directions in the Sociology of Collective Memory and Commemoration. Sociology Compass, 4(7) 442-453.

Cooper, M. (2006). The Pacific War Battlefields: Tourist Attractions or War Memorials. International Journal of Tourism Research, 8, 213-222.

Cooper, M. (2007). Post-Colonial Representations of Japanese Military Heritage: Political and Social Aspects of Battlefield Tourism in the Pacific and East Asia. In C. Ryan (Ed.), Battlefield Tourism: History, Place and Interpretation, Oxford, Elsevier, 73-86.

Creswell, J. W. (2009). Research Design: Qualitative, Quantitative, and Mixed Methods Approaches, Third Edition. USA: Sage Publications.

Çanakkale İl Kültür ve Turizm Müdürlüğü [Çanakkale Provincial Directorate of Culture and Tourism]. URL: http://www.canakkalekulturturizm.gov.tr/ (Accessed on 26.11.2016).

Dark Tourism. (2015). Oxford Dictionary: Language Matters. URL: http://www.oxforddictionaries.com/definition/english/dark-tourism?q=dark+tourism (Accessed on 11.12.2015).

Donoghue, J. and Tranter, B. (2015). The Anzacs: Military Influences on Australian Identity. Journal of Sociology, 51(3), 449-463.

Dore, L. (2006). Gallipoli: A Visitor Profile. Historic Environment, 19(2), 46-51.

Dunkley, R., Morgan, N. \& Westwood, S. (2011). Visiting the Trenches: Exploring Meanings and Motivations in Battlefield Tourism. Tourism Management, 32(4), 86o-868.

Farmaki, A. (2013). Dark Tourism Revisited: A Supply/Demand Conceptualisation. International Journal of Culture, Tourism and Hospitality Research, 7(3), 281-292.

Foley, M. and Lennon, J. (1996a). Editorial: Heart of Darkness. International Journal of Heritage Studies, 2(4), 195-197.

Foley, M. and Lennon, J. (1996b). JFK and Dark Tourism: A Fascination with Assassination. International Journal of Heritage Studies, 2(4), 198-211.

Gatewood, J. B. and Cameron, C. M. (2004). Battlefield Pilgrims at Gettysburg National Military Park. Ethnology, 43(3), 193-216.

Goatcher, J. and Brunsden, V. (2011). Chernobyl and the Sublime Tourist. Tourist Studies, 11(2), 115-137. 
Gordon, B. M. (1998). Warfare and Tourism: Paris in World War II. Annals of Tourism Research, 25(3), 616-638.

Graham, J. (2008). Young New Zealanders and the Great War: Exploring the Impact and Legacy of the First World War, 1914-2014. Paedagogica Historica, 44(4), 429-444.

Hall, C. M. (2002). ANZAC Day and Secular Pilgrimage. Tourism Recreation Research, 27(2), 83-87.

Hall, J. and Basarin, J. (2009). Anzac Day Commemorations at Gallipoli and the Economic Effects of Attendance. CAUTHE 2009: See Change: Tourism \& Hospitality is a Dynamic World [online]. Carlsen, J., Hughes, M., Holmes, K., Jones, R. (eds.). 1871-1885. URL: https://search.informit.com.au/documentSummary;dn=171983306327206;res=IELBUS (Accessed on 19.12.2016).

Hall, J., Basarin V. J. and Binney, L. L. (2010). An Empirical Analysis of Attendance at a Commemorative Event: Anzac Day at Gallipoli. International Journal of Hospitality Management, 29(2), 245-253.

Hartmann, R. (2014). Dark Tourism, Thanatourism, and Dissonance in Heritage Tourism Management: New Directions in Contemporary Tourism Research. Journal of Heritage Tourism, 9(2), 166-182.

Hayllar, B. and Griffin, T. (2005). The Precinct Experience: A Phenomenological Approach. Tourism Management, 26(4), 517-528.

Hede, A. M. and Hall J. (2006). Evoked Emotions: A Textual Analysis Within the Context of Pilgrimage Tourism to Gallipoli. In Lees, M. C., Davis, T. and Gregory, G. (eds.), Asia-Pacific Advances in Consumer Research Volume 7. Sydney, Australia: Association for Consumer Research, 419-425.

Henderson, J. C. (2000). War as a Tourist Attraction: The Case of Vietnam. International Journal of Tourism Research, 2(4), 269-28o.

Hennink, M., Hutter, I. and Bailey, A. (2011). Qualitative Research Methods, Sage: Great Britain.

Hurt, D. A. (2010). Reinterpreting the Washita Battlefield National Historic Site. The Geographical Review, 100(3), 375-393.

Hyde, K. F. and Harman S. (2011). Motives for a Secular Pilgrimage to the Gallipoli Battlefields. Tourism Management, 32(6), 1343-1351.

Isaac, R. K., Nawijn, J., van Liempt, A., and Gridnevskiy, K. (2019). Understanding Dutch visitors' motivations to concentration camp memorials. Current Issues in Tourism, 22(7), 747-762.

Iles, J. (2008). Encounters in the Fields: Tourism to the Battlefields of the Western Front. Journal of Tourism and Cultural Change, 6(2), 138-154.

Irimiás, A. (2014). The Great War Heritage Site Management in Trentino, Northern Italy. Journal of Heritage Tourism, 9(4), 317-331.

Isaac, R. K. and Çakmak, E. (2013). Understanding Visitor's Motivation at Sites of Death and Disaster: The Case of former Transit Camp Westerbrook, the Netherlands. Current Issues in Tourism, 17(2), 164-179.

Ivanova, P., and Light, D. (2018). 'It's not that we like death or anything': exploring the motivations and experiences of visitors to a lighter dark tourism attraction. Journal of Heritage Tourism, 13(4), 356369.

Johnston, T. (2011). Thanatourism and the Commodification of Space in Post-War Croatia and Bosnia. In Shapley, R. and Stone, P. R. (eds.) Tourist Experience: Contemporary Perspectives. UK: Routledge, 43-55.

Kang, E. J., Scott N., Lee T. J. and Ballantyne R. (2012). Benefits of Visiting a 'dark tourism' Site: The Case of the Jeju April 3rd Peace Park Korea. Tourism Management, 33(2), 257-265.

Kang, E. J., Lee, T. J., and Han, J. S. (2018). The influence of enduring involvement on tragedy-related tourism experiences. Journal of Travel Research, 57(5), 658-670.

Kaya, O. (2006). Ölüm Turizmi: Gelibolu Yarımadası Tarihi Milli Parkı'nı Ziyaret Eden Turistlerin Ziyaret Motivasyonlarını Anlamaya Yönelik Bir Araştırma ve Sonuçları [Death Tourism: An Investigation and Results for Getting Insight towards the Visitor Motivations of the Travellers 
Visiting Gallipoli Historical National Park]. Yayımlanmamış Yüksek Lisans Tezi [Unpublished Master Thesis]. Çanakkale On Sekiz Mart Üniversitesi Sosyal Bilimler Enstitüsü Turizm İşletmeciliği Ana Bilim Dalı, Çanakkale.

Kidron, C. A. (2013). Being There Together: Dark Family Tourism and The Emotive Experience of CoPresence in The Holocaust Past. Annals of Tourism Research, 41, 175-194.

Knox, D. (2006). The Sacralised Landscapes of Glencoe: From Massacre to Mass Tourism, and Back Again. International Journal of Tourism Research, 8(3), 185-197.

Kokkranikal, J., Yang, Y. S., Powell, R. and Booth, E. (2015). Motivations in Battlefield Tourism: The Case of '1916 Easter Rising Rebellion', Dublin. In Katsoni, V., Stratigea A. (eds.) Tourism and Culture in the Age of Innovation, Second International Conference, IACuDiT, Athens 2015, 321-330.

Korstanje, M. E. (2011). Detaching the Elemantary Forms of Dark-Tourism. Anatolia, 22(3), 424-427.

Kozak, M. A. and Bahçe S. (2012). Özel İlgi Turizmi [Special Interest Tourism]. İkinci Baskı Ankara: Detay Yayıncılık.

Kurnaz, H. A., Çeken H. and Kılıç B. (2013). Hüzün Turizmi Katılımcılarının Seyahat Motivasyonlarının Belirlenmesi [Determination of Dark Tourism Participants' Motivations]. İșletme Araştırmaları Dergisi, 5(2), 57-73.

Lagos, E., Harris A. and Sigala, M. (2015). Emotional Language For Image Formation and Market Segmentation in Dark Tourism Destinations: Findings From Tour Operators' Websites Promoting Gallipoli. TOURISMOS: An International Multidisciplinary Journal of Tourism, 10(2), 153-170.

Lennon, J. J. and Foley, M. (1999). Interpretation of the Unimaginable: The US Holocaust Memorial Museum, Washington, DC, and 'Dark Tourism. Journal of Travel Research, 38(1), 46-50.

Lennon, J. (2005). Journeys into Understanding: What is Dark Tourism? The Guardian, October 23. URL: $\quad$ http://www.theguardian.com/travel/2005/oct/23/darktourism.observerescapesection (Accessed on 24.11.2015).

Leopold, T. (2007). A Proposed Code of Conduct for War Heritage Sites. In Ryan, C. (ed.). Battlefield Tourism: History, Place and Interpretation, Oxford, Elsevier, 49-58.

Light, D. (2007). Dracula tourism in Romania cultural identity and the state. Annals of tourism research, 34(3), 746-765.

Light, D. (2017). Progress in dark tourism and then a tourism research: An uneasy relationship with heritage tourism. Tourism Management, 61, 275-301.

Lin, Y., Kelemen, M., and Tresidder, R. (2018). Post-disaster tourism: building resilience through community-led approaches in the aftermath of the 2011 disasters in Japan. Journal of Sustainable Tourism, 26(10), 1766-1783.

Lippard, L. R. (1999). On the Beaten Track: Tourism, Art and Place. New York: The New Press.

Liyanage, S., Stefaniak, J. A. C. and Powell, R. (2015). Dark Destinations: Visitor Reflections from a Holocaust Memorial Site. International Journal of Tourism Cities, 1(4), 282-298.

MacCannell, D. (1976). The Tourist: A New Theory of the Leisure Class. London: University of California Press.

McKenna, M. and Ward S. (2007). It was really moving, mate': The Gallipoli Pilgrimage and Sentimental Nationalism in Australia, Australian Historical Studies, 38(129), 141-151.

McKercher, B. (2002). Towards a Classification of Cultural Tourists. International Journal of Tourism Research, 4(1), 29-38.

Miles, W. (2002). Auschwitz: Museum Interpretation and Darker Tourism. Annals of Tourism Research, 29(4), 1175-1178.

Miles, S. (2014). Battlefield Sites as Dark Tourism Attractions: An Analysis of Experience. Journal of Heritage Tourism, 9(2), 134-147. 
Miller, D. S. and Gonzalez, C. (2013). When Death is the Destination: The Business of Death TourismDespite Legal and Social Implications. International Journal of Culture, Tourism and Hospitality Research, 7(3), 293-306.

Misztal, B. A. (2003). Theories of Social Remembering, Maidenhead: Open University Press.

Muzaini, H., Teo P. and Yeoh B. S. A. (2007). Intimations of Postmodernity in Dark Tourism: The Fate of History at Fort Siloso, Singapore. Journal of Tourism and Cultural Change, 5(1), 28-45.

Nawijn, J., \& Fricke, M. C. (2015). Visitor emotions and behavioral intentions: The case of concentration camp memorial Neuengamme. International Journal of Tourism Research, 17(3), 221-228.

Ozer, S. U., Ersoy, G. K. and Tuzunkan, D. (2012). Dark Tourism in Gallipoli: Forecast Analysis to Determine Potential of Australian Visitors. Procedia-Social and Behavioral Sciences, 41, 386-393.

Pearce, P. L. and Caltabiano, M. L. (1983). Inferring Travel Motivation from Travelers' Experiences. Journal of Travel Research, 22(2), 16-20.

Pennell, C. (2018). Taught to remember? British youth and First World War centenary battlefield tours. Cultural Trends, 27(2), 83-98.

Pieris, A. (2014). Southern Invasions: Post-War Tourism in Sri-Lanka. Postcolonial Studies, 17(3), 266285 .

Piersig, C. B. (1994). Gallipoli Revisited: An Operational Assessment of the 1915 Dardanelles Campaign, Operations Research Paper, Naval War College, Newport: Rhode Island.

Podoshen, J. S. and Hunt, J. M. (2011). Equity Restoration, the Holocaust and Tourism of Sacred Sites. Tourism Management, 32(6), 1332-1342.

Podoshen, J. S. (2017). Trajectories in Holocaust tourism. Journal of Heritage Tourism, 12(4), 347-364.

Preece, T and Price, G. G. (2005). Motivations of Participants in Dark Tourism: A Case Study of Port Arthur, Tasmania, Australia. In Aicken, M., Page, S. J. and Ryan, C. (eds.) Taking Tourism to the Limits: Issues, Concepts and Managerial Perspectives (Advances in Tourism Research). Routledge: UK, 191-198.

Prentice, R. C., Witt, S. F. and Hamer, C. (1998). Tourism as Experience: The Case of Heritage Parks. Annals of Tourism Research, 25(1), 1-24.

Prideaux, B. (2007). Echoes of War: Battlefield Tourism. In Ryan, C. (Ed.), Battlefield Tourism: History, Place and Interpretation. Oxford: Elsevier, 17-28.

Powell, R. and Iankova, K. (2016). Dark London: Dimensions and Characteristics of Dark Tourism Supply in the UK Capital. Anatolia, 27(3), 339-351.

Powell, R. and Kennell, J. (2016). Dark Cities? Developing a Methodology for Researching Dark Tourism in European Cities. In V. Katsoni, \& A. Stratigea (Eds.), Tourism and culture in the age of innovation (pp. 303-319). Heidelburg: Springer.

Raine, R. (2013). A Dark Tourism Spectrum. International Journal of Culture, Tourism and Hospitality Research, 7(3), 242-256.

Rojek, C. (1993). Ways of Escape: Modern Transformations of Leisure and Travel. London: Macmillan.

Ryan, C. (2007a). Introduction. In Ryan, C. (Ed.), Battlefield Tourism: History, Place and Interpretation, Oxford, Elsevier, 1-10.

Ryan, C. (2007b). Battlefield Tourism: History, Place and Interpretation, Oxford, Elsevier, 249-254.

Ryan, C. and Cave, J. (2007). Cambridge Armistice Day Celebrations: Making a Carnival of War and the Reality of Play. In C. Ryan (Ed.), Battlefield Tourism: History, Place and Interpretation, Oxford, Elsevier: 177-186.

Sackett, L. (1985). Marching into the Past: Anzac Day Celebrations in Adelaide. Journal of Australian Studies, 9(17): 18-30.

Scates, B. (2002). In Gallipoli's Shadow: Pilgrimage, Memory, Mourning and The Great War. Australian Historical Studies, 33(119), 1-21. 
Scates, B. (2006). Return to Gallipoli: Walking the Battlefields of the Great War, Cambridge University Press: Australia.

Seaton, A. V. (1996). Guided by the Dark: From Thanatopsis to Thanatourism. International Journal of Heritage Studies, 2(4), 234-244.

Seaton, A. V. (1999). War and Thanatourism: Waterloo 1815-1914. Annals of Tourism Research, 26(1), 130158.

Seaton, A. V. (2002). Thanatourism's Final Frontiers? Visits to Cemeteries, Churchyards and Funerary Sites as Sacred and Secular Pilgrimage. Tourism Recreation Research, 27(2), 73-82.

Sion, B. (2014). Conflicting Sites of Memory in Post-Genocide Cambodia. In Sion, B (Ed.), Disaster Sites as Recreational Landscape, Seagull, India, 97-120.

Sharpley, R. (2005). Travels to the Edge of Darkness: Towards a Typology of "Dark Tourism". In Aicken, M., Page, S. J. and Ryan, C. (eds.) Taking Tourism to the Limits: Issues, Concepts and Managerial Perspectives (Advances in Tourism Research). Routledge: UK, 215-226.

Sharpley, R. (2009). Shedding Light on Dark Tourism: An Introduction. In Sharpley, R. and Stone, P. (eds.) The Darker Side of Travel: The Theory and Practice of Dark Tourism. UK: Channel View Publications, 3-22.

Sharpley, R. and Stone, P. R. (2009). (Re)presenting the Macabre: Interpretation, Kitschification and Authenticity. In Sharpley, R. and Stone, P. R. (eds.) The Darker Side of Travel: The Theory and Practice of Dark Tourism. UK: Channel View Publications, 109-128.

Slade, P. (2003). Gallipoli Thanatourism: The Meaning of ANZAC. Annals of Tourism Research, 20(4), 779-794.

Smith, V. L. (1998). War and Tourism: An American Ethnography. Annals of Tourism Research, 25(1), 202-227.

Smith, N. and Croy, W. G. (2005). Presentation of Dark Tourism: Te Wairoa: The Buried Village. In Aicken, M., Page, S. J. and Ryan, C. (eds.) Taking Tourism to the Limits: Issues, Concepts and Managerial Perspectives (Advances in Tourism Research). UK: Routledge, 199-213.

Smith, H. (2007). Seventy Years of Waiting: A Turning Point of Interpreting the Spanish Civil War? In Ryan, C. (ed.) Battlefield Tourism: History, Place and Interpretation. Oxford: Elsevier, 99-110.

Somme and Ypres Battlefields of the Great War. (2015). 1914-1918. URL: http://www.battlefieldtours.com/ (Accessed on 28.12.2015).

Stephens, J. R. (2014). Sacred Landscapes: Albany and Anzac Pilgrimage. Landscape Research, 39(1), 2139.

Sternberg, E. (1999). The Economy of Icons. Westport, USA: Praeger.

Stone, P. R. (2005). Dark Tourism Consumption: A Call for Research. E-Review of Tourism Research (eRTR), 3(5), 109-117.

Stone, P. R. (2006). A Dark Tourism Spectrum: Towards a Typology of Death and Macabre Related Tourist Sites, Attractions and Exhibitions. Tourism: An Interdisciplinary International Journal, 54(2), 145-16o.

Stone, P. R. (2009). It is a Bloody Guide: Fun, Fear and Lighter Side of Dark Tourism at the Dungeon Visitor Attractions, UK. In Sharpley, R. and Stone, P. R. (eds.) The Darker Side of Travel: The Theory and Practice of Dark Tourism. UK: Channel View Publications, 167-185.

Stone, P. R. (2013a). Dark Tourism, Heterotopias and Post-Apocalyptic Places: The Case of Chernobyl. In L. White and E. Frew. (eds.) Dark Tourism and Place Identity. Melbourne: Routledge, 1-19.

Strange, C. and Kempa M. (2003). Shades of Dark Tourism: Alcatraz and Robben Island. Annals of Tourism Research, 30(2), 386-405.

Stone, P., and Sharpley, R. (2008). Consuming dark tourism: A thanatological perspective. Annals of tourism Research, 35(2), 574-595. 
Vázquez, D. G. (2018). Dark tourism and memorial tourism: Nexus and divergences between theoretical models. European Journal of Tourism Research, 20, 46-58.

Virgili, S., Delacour, H., Bornarel, F., and Liarte, S. (2018). 'From the Flames to the Light': 100 years of the commodification of the dark tourist site around the Verdun battlefield. Annals of Tourism Research, 68, 61-72.

West, B. (2008). Enchanting Pasts: The Role of International Civil Religious Pilgrimage in Reimagining National Collective Memory. Sociological Theory, 26(3), 258-270.

Willis, E. (2014). Theatricality, Dark Tourism and Ethical Spectatorship: Absent Others. Palgrave Macmillan.

Wilson, J. Z., Hodgkinson, S., Piché, J., and Walby, K. (eds.). (2017). The Palgrave Handbook of Prison Tourism. UK: Springer.

Winter, J. (2008). Sites of Memory and the Shadow of War. In Erll, A. and Nünning, A. (eds.) Media and Cultural Memory. Germany: Walter De Gruyter, 61-74.

Winter, C. (2009). Tourism, Social Memory and the Great War. Annals of Tourism Research, 36(4), 607626.

Winter, C. (2011a). First World War Cemeteries: Insights from Visitor Books. Tourism Geographies, 13(3), $462-479$.

Winter, C. (2011b). Battlefield Visitor Motivations: Explorations in the Great War Town of Ieper, Belgium. International Journal of Tourism Research, 13(2), 164-176.

Wheatley, R. and James L. (2014). 'Such a Great Space of Water between Us': Anzac Day in Britain, 191639. Australian Historical Studies, 45(2), 220-241.

Wright, D., and Sharpley, R. (2018). Local community perceptions of disaster tourism: the case of L'Aquila, Italy. Current Issues in Tourism, 21(14), 1569-1585.

Yankovska, G. and Hannam, K. (2014). Dark and Toxic Tourism in the Chernobyl Exclusion Zone. Current Issues in Tourism, 17(10), 929-939.

Yeneroğlu-Kutbay, E. and Aykac, A. (2016). Battlefield Tourism at Gallipoli: The Revival of Collective Memory, the Construction of National Identity and the Making of a Long-distance Tourism Network. Alma Tourism Special Issue, 7(5), 61-83.

Young, M. (1999). The Relationship between Tourist Motivations and the Interpretation of Place Meanings. Tourism Geographies, 1(4), 387-405.

Yuill, S. M. (2003). Dark Tourism: Understanding Visitor Motivation at Sites of Death and Disaster, MSc. Thesis, Texas A\&M University.

Zheng, C., Zhang, J., Qian, L., Jurowski, C., Zhang, H., and Yan, B. (2018). The inner struggle of visiting 'dark tourism'sites: examining the relationship between perceived constraints and motivations. Current Issues in Tourism, 21(15), 1710-1727.

Received: 15/04/2019

Accepted: 01/07/2019

Coordinating editor: Stanislav Ivanov 